Article

\title{
Synergistic Passivation of Fly Ash and TMT on Heavy Metals in Sewage Sludge
}

\author{
Dong-Fang Wang, Shi-He Li, Xian-Qing Wang, Ling-Xu Li and Xuan Zhang * \\ College of Environmental Science and Engineering, Qilu University of Technology \\ (Shandong Academy of Sciences), Ji'nan 250353, China; m17863682303@163.com (D.-F.W.); \\ 13969027757@163.com (S.-H.L.); 18364195759@139.com (X.-Q.W.); lilingxu4you@163.com (L.-X.L.) \\ * Correspondence: zx@qlu.edu.cn; Tel.: +86-531-89631680
}

Received: 11 November 2018; Accepted: 10 December 2018; Published: 12 December 2018

check for updates

\begin{abstract}
Large amounts of fly ash and sewage sludge are produced annually in China. The treatment and disposal of such byproducts have become urgent problems that need to be solved. In order to achieve the possibility of realizing land applications for sewage sludge, fly ash and trimercapto-striazine trisodium salt (TMT) were used as immobilizing agents, and their passivation effects on four kinds of heavy metals $(\mathrm{Cu}, \mathrm{Ni}, \mathrm{Pb}$, and $\mathrm{Zn})$ were evaluated. The results showed that the resulting sewage sludge met Chinese standard GB/T23486-2009. When the addition was 10-20\% fly ash or $0.4-0.6 \%$ TMT, the optimum immobilization effect was obtained. The synergistic passivation of $20 \%$ fly ash $+0.5 \%$ TMT was superior to that of either fly ash or TMT alone. The addition of sewage sludge during the ryegrass growth process significantly increased the plant height, the number of tillers, the chlorophyll content, and the biomass of the ryegrass over the brown soil. The adverse effect of the heavy metals on the ryegrass growth could be alleviated by the passivation effect of fly ash and TMT. The immobilization performance of the fly ash was mainly due to the formation of precipitation and the ion exchange, while that of TMT was due to chelate precipitation.
\end{abstract}

Keywords: heavy metals; sewage sludge; fly ash; trimercapto-s-triazine trisodium salt; immobilization

\section{Introduction}

With the acceleration of urbanization in China, the overall output of sewage sludge has been obviously increasing with the rise in the volume of wastewater and its treatment. In 2016, the annual sewage sludge production reached 39.5 million tons (containing $80 \%$ moisture) [1]. Sludge accumulation not only occupies a large amount of land, causing environmental pollution, but also is a serious burden for urban sewage treatment plants. Therefore, the reduction, the stabilization, the safe disposal, and the resource utilization of sewage sludge have become urgent problems in China [2,3].

Sewage sludge, a byproduct of biological wastewater treatment processes, is rich in organic matter $(\mathrm{OM})$, nitrogen $(\mathrm{N})$, phosphorus $(\mathrm{P})$, and other trace elements. Its land applications include the facilitation of the recycling of nutrients for accelerating plant growth and improving soil characteristics, such as porosity, bulk density, and water retention capacity [4-6]. However, sewage sludge might contain toxic heavy metals, and the long-term use of sewage sludge on the land would inevitably result in the accumulation of toxic levels of heavy metals in the soil, which is considered to be the main obstacle for the practical application of sewage sludge on the land [7].

Many studies have been conducted to immobilize the heavy metals in sewage sludge [8,9]. The presence of such heavy metals could be decreased via reactions with chemical passivating agents through precipitation, chelation, sorption, and ion exchange. The generally used agents include alkaline compounds, aluminosilicates, phosphorus-containing materials, and sulfides [10]. 
Fly ash, a byproduct produced in coal-fired power plants, is mainly composed of $\mathrm{SiO}_{2}, \mathrm{Al}_{2} \mathrm{O}_{3}$, $\mathrm{CaO}, \mathrm{Fe}_{2} \mathrm{O}_{3}, \mathrm{MgO}$, unburned carbon, and sulfate $\left(\mathrm{SO}_{4}{ }^{2-}\right)$ [11]. Its irregular accumulation and improper disposal have allowed it to contaminate large areas of land, resulting in the degradation of the soil and increased risk to both human health and the environment. Fine particles of fly ash, small enough to escape emission control devices, are easily suspended in the air and have become a main source of air pollution. In 2016, the fly ash output in China was 5.65 billion tons [12]. The huge quantity of fly ash produced annually poses serious environmental concerns. China's relatively rich coal deposits mean that coal is likely to be the dominant fuel for the generation of power in China for a long time in the future. Thus, developing appropriate measures for the safe disposal of fly ash and discovering practical means of utilizing fly ash are very necessary for sustainable management [13].

In recent years, many scientific studies have been conducted relating to up-cycling technologies for fly ash, which, in turn, have significantly increased the value-added applications of fly ash [14-16]. Fly ash, being mostly alkaline, can transform heavy metals in the soil into a stable state, and it has been widely used to remediate heavy metal-contaminated soil $[17,18]$. Practical applications of fly ash on the land can improve the physical properties of the soil, including the texture, the bulk density, the and water retention capacity $[19,20]$. Fly ash contains most of the essential plant nutrients except OM and $\mathrm{N}$ [11], while sewage sludge is rich in OM and N. Thus, the mixture of fly ash and sewage sludge would not only provide appreciable amount of nutrients for plant growth, but would also immobilize the heavy metals in sewage sludge. The application of such a mixture on the land could, therefore, benefit the environment and ecology by enhancing the plant yield and solving the disposal problem regarding fly ash and sewage sludge.

In order to improve the stabilization effect on the heavy metals in sewage sludge, trimercapto-striazine trisodium salt (TMT) was combined with fly ash. Their synergistic passivation effect on the heavy metals and their impact on plant growth needed to be systematically studied. The objectives of this study were as follows: (1) to investigate the properties of sewage sludge and fly ash to evaluate whether they are appropriate for land application, (2) to evaluate the immobilization effect of fly ash and TMT on the heavy metals in sewage sludge, (3) to compare the effect of immobilized and un-immobilized sewage sludge on ryegrass growth, and (4) to analyze the passivation mechanism of fly ash and TMT on the heavy metals in sewage sludge. The effective immobilization of the heavy metals in sewage sludge could solve the problem of the pollution caused by heavy metals during the process of the land use of sewage sludge. At the same time, this proposal provides a new idea for the resource utilization of fly ash.

\section{Materials and Methods}

\subsection{Collection and Preparation of the Materials}

The dewatered sewage sludge (15-20\% dry solid content) was collected from the Changqing Wastewater Treatment Plant in Ji'nan, Shandong Province, China. Before the sewage sludge was de-moisturized via centrifuge, a large amount of $\mathrm{CaO}$ was added to make the sewage sludge easier to dewater and to reduce the pathogens and the availability of the heavy metals. The dewatered sewage sludge was air dried, homogenized, and crushed by a grinder. The fly ash was obtained from a coal-fired thermal power plant in Ji'nan. Brown soil from the campus of Qilu University of Technology was selected for the plant growth experiment. All the samples of soil, sewage sludge, and fly ash were passed through a 60 mesh sieve for further analysis and the plant cultivation experiment.

The TMT, chosen as an organic sulfur passivating agent, was obtained from Xinjiang Environmental Protection Materials Co., Ltd. in Lianyungang, Jiangsu Province. The TMT was 15\% aqueous solution, which could form stable precipitation with 1 valence and 2 valence metal ions, such as $\mathrm{Ni}^{2+}, \mathrm{Pd}^{2+}$, $\mathrm{Cu}^{2+}, \mathrm{Zn}^{2+}, \mathrm{Cd}^{2+}, \mathrm{Ag}^{+}$, and so on. 


\subsection{Analytical Methods}

\subsubsection{Determination of the Physico-Chemical Properties}

The $\mathrm{pH}$ value was determined in a 1:5 $(w / v)$ suspension of the solid sample and distilled water using a $\mathrm{pH}$ meter. The OM, electricity conductivity (EC), cation exchange capacity (CEC), and moisture content were analyzed by the standard laboratory procedures. Total nitrogen (TN) was measured by semi-micro Kjeldahl method. Total phosphorus (TP) was determined by Mo-Sb colorimetric method, after the sample was digested by $\mathrm{H}_{2} \mathrm{SO}_{4}-\mathrm{HClO}_{4}$. Total potassium (TK) was determined by an alkaline fusion-flame photometric method [21].

\subsubsection{Extraction and Determination Methods for the Heavy Metals}

The total concentrations of the heavy metals were determined by digesting a known quantity of the sample using $\mathrm{HNO}_{3}-\mathrm{H}_{2} \mathrm{O}_{2}$ [22]. The acid digestion suspensions were then filtered through a filter membrane $(0.45 \mu \mathrm{m})$, and the filtrates were measured to determine the total metal concentrations by inductively coupled plasma optical emission spectroscopy (ICP-OES, Optima 2000DV, Perkin Elmer, American).

The chemical fractions of the heavy metals were measured by the four-stage Community Bureau of Reference (BCR) sequential procedure. The BCR procedure was basically a revised method of the five-stage sequential extraction procedure initially put forward by Tessier et al. [23-25]. It has been widely used in the assessment of metal bioavailability in various matrices (e.g., sediment [26,27], soil [28,29], sludge [30,31], ash [32,33] and other industrial residues [34-36]). In this paper, a modified BCR process was used to analyze the speciation of the heavy metals in sewage sludge, brown soil, and fly ash. During the extraction process, the heavy metals in each sample were classified into four fractions-the exchangeable fraction, the reducible fraction, the oxidizable fraction, and the residual fraction-land each fraction showed different bioavailability. The exchangeable fraction, combined with carbonates, was easily migrated into the soil solution and considered to be bioavailable. The reducible fraction and the oxidizable fraction were potentially bioavailable. The residual fraction was thought to be unavailable to plants $[37,38]$.

The extraction steps are shown in Figure 1.

The supernatant obtained by the extraction process was treated by the previous method for the determination of the total concentrations of the heavy metals. For each extraction step, a blank experiment was conducted with an equal amount of the different reagents. All the containers in the experiments were previously soaked overnight with $20 \%(v / v) \mathrm{HNO}_{3}$ and then rinsed with ultrapure water. All the reagents were of analytical grade and contained very low concentrations of trace metals. The ultrapure water was from a Millipore Milli Q system. Normal precautions for trace metal analysis were observed throughout the process.

A check of the results of the modified BCR process was conducted by comparing the sum of the four fractions with their total concentrations. The results indicated that the sum of the four fractions was consistent with the total heavy metal concentration, which showed that the modified BCR sequential extraction procedure used to determine the speciation of the heavy metals in the fly ash, sewage sludge, and brown soil was reliable. 


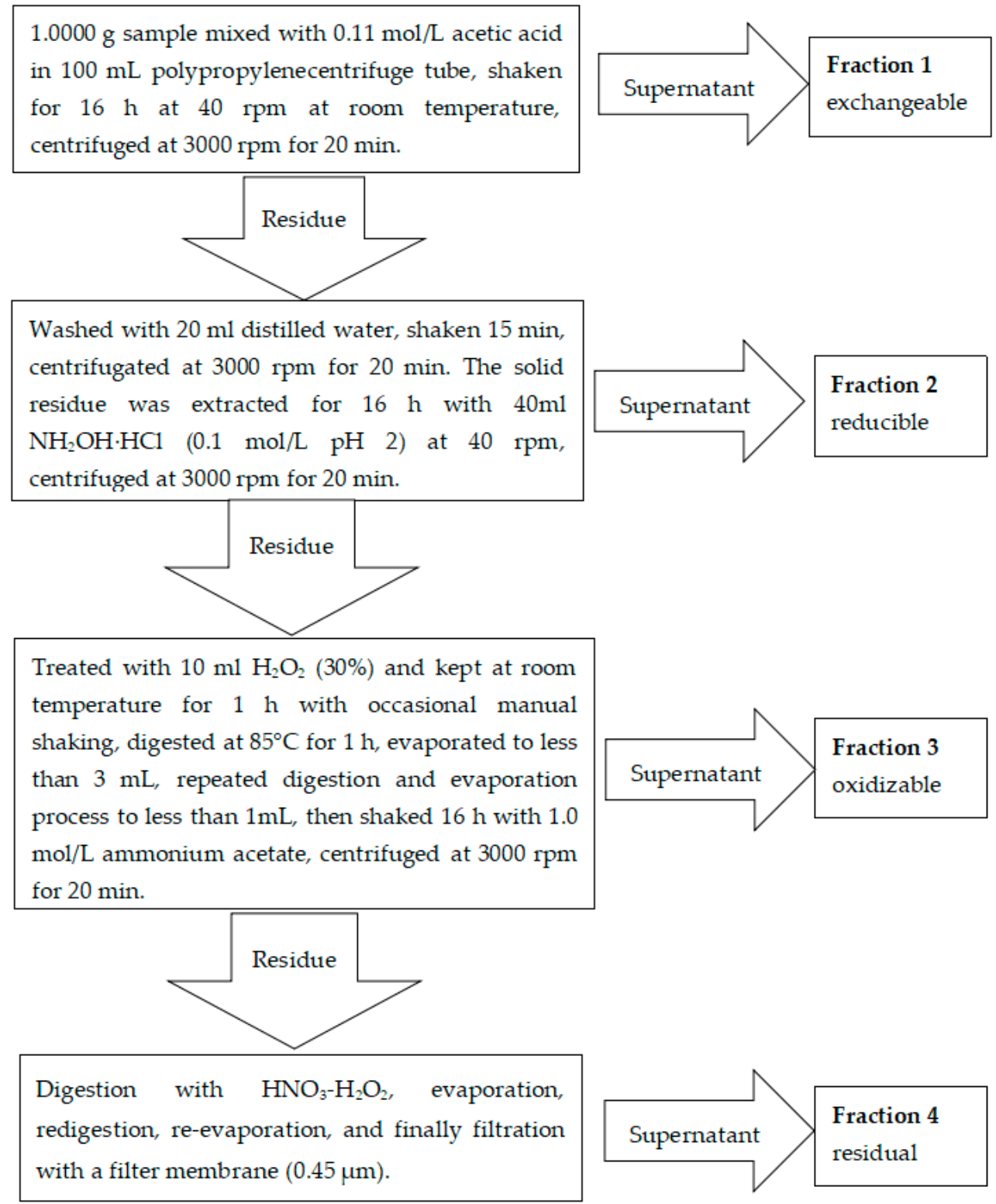

Figure 1. Community Bureau of Reference (BCR) sequential extraction procedure.

\subsection{Immobilization Treatment of the Sewage Sludge}

Fly ash was mixed with the dewatered sewage sludge at the weight proportions of $0 \%, 10 \%, 20 \%$, $30 \%$, and $40 \%$, respectively. After being mixed evenly, the mixtures were maintained at $50 \%$ water content for 5 days at room temperature to ensure the complete immobilization of the heavy metals in the sewage sludge. They were then air dried, homogenized, and crushed by a grinder. Then, they were passed through a 60 mesh sieve for further analysis and the plant cultivation experiment. The samples were labeled as F0, F10, F20, F30, and F40, respectively.

The air-dried fly ash-sewage sludge mixtures were mixed thoroughly with the brown soil at the weight proportion of 1:4. In order to achieve the blending homogeneity of the fly ash, sewage sludge, and brown soil, an appropriate amount of distilled water was poured into the mixtures and then air dried at room temperature. The process was conducted three times to ensure that the mixtures were blended thoroughly.

A $15 \%$ TMT solution was mixed with the sewage sludge slurry (50\% water content) at the weight proportions of $0 \%, 0.2 \%, 0.4 \%, 0.6 \%$, and $0.8 \%$, respectively. Because TMT could react with the heavy 
metal ions rapidly, the passivation time was not considered. The mixtures were air dried, homogenized, and crushed by a grinder. Then, they were passed through a 60 mesh sieve for further analysis and the plant cultivation experiment. The samples were labeled as T0, T0.2, T0.4, T0.6, and T0.8, respectively.

The synergistic immobilization of the fly ash and TMT on the heavy metals was investigated by adding $0.5 \%$ TMT into sample F20. The sample treated by 20\% fly ash and $0.5 \%$ TMT was labeled as F20T0.5.

The speciation change of the residual heavy metals ( $\Delta$ residual fraction) was obtained by subtracting the percentage of residual fraction in the raw sewage sludge from the percentage of the residual fraction in the immobilized sewage sludge. If the value was positive, it meant that the residual state had increased, and the immobilization effect on the heavy metals had improved. The larger the positive value, the better the passivation effect. On the contrary, if the value was negative, it could be concluded that part of the residual fraction was activated by the treatment.

The speciation change of the exchangeable heavy metals ( $\Delta$ exchangeable fraction) was obtained by subtracting the percentage exchangeable fraction in the immobilized sewage sludge from the percentage exchangeable fraction in the raw sewage sludge. If the value was positive, it meant that the exchangeable fraction increased, and the treatment had a certain passivation effect on the heavy metals. If the value was negative, it could be concluded that the heavy metals were activated.

\subsection{Ryegrass Planting Experiment}

The prepared samples of brown soil and sewage sludge were filled into flowerpots $(21 \mathrm{~cm} \times$ $49 \mathrm{~cm} \times 20 \mathrm{~cm}$ ). The three treatments, including the control treatment, the un-stabilized sewage sludge treatment (USS), and the stabilized sewage sludge treatment (SSS) are shown in Table 1, and there were three replications for each treatment. No fertilizer was applied before and during the planting experiment. The ryegrass, in good health and the same age, was collected from campus' lawn in the same size, including the area, height, and biomass. The flowerpots were placed in a glasshouse at $25-30{ }^{\circ} \mathrm{C}$ and $50-70 \%$ relative humidity and ensured $14 \mathrm{~h}$ of natural daylight per day. The plants were permitted to grow for 42 days. These flowerpots were watered using distilled water daily to maintain $70 \%$ of the field water retention capacity. In each parallel treatment, 10-12 strains were selected randomly to measure their plant height, the number of tillers, and the chlorophyll content. The chlorophyll content was determined by an ethanol extraction method [39,40]. The aboveground part was used to determine the biomass, including the fresh weight and dry weight.

Table 1. The proportions of the various substrates used in the three treatments.

\begin{tabular}{ccccc}
\hline Treatment & Brown Soil & Sewage Sludge & Fly Ash & TMT \\
\hline Control treatment & $100 \%$ & 0 & 0 & 0 \\
USS treatment & $80 \%$ & $20 \%$ & 0 & 0 \\
SSS treatment & $79.50 \%$ & $16 \%$ & $4 \%$ & $0.50 \%$ \\
\hline
\end{tabular}

Each value represented on an air-dried weight base. TMT: trimercapto-s-triazine trisodium salt; USS: un-stabilized sewage sludge; and SSS: stabilized sewage sludge.

\section{Results and Discussion}

\subsection{Characteristics of the Sewage Sludge, Fly Ash, and Brown Soil}

The physico-chemical properties and heavy metal contents of the selected fly ash, sewage sludge, and brown soil are listed in Table 2 . The $\mathrm{pH}$ value of the sewage sludge was $6.89 \pm 0.13$, which was close to the $\mathrm{pH}$ of the brown soil $(6.82 \pm 0.04)$; therefore, the land use of the sewage sludge would have little effect on the $\mathrm{pH}$ of the soil. The $\mathrm{pH}$ value of the fly ash was as high as $10.88 \pm 0.02$, which was mainly due to its high content of $\mathrm{CaO}$ and $\mathrm{MgO}$ [41]. The high $\mathrm{pH}$ value was beneficial to transform the active heavy metal fraction into the residual fraction and helped to reduce their bioavailability [17,42]. Thus, fly ash has been commonly used as a kind of passivating agent to stabilize heavy metals. 
Table 2. Physical and chemical properties of the sewage sludge, fly ash, and brown soil.

\begin{tabular}{cccc}
\hline Samples & Sewage Sludge & Brown Soil & Fly Ash \\
\hline $\mathrm{pH}$ & $6.89 \pm 0.13$ & $6.82 \pm 0.04$ & $10.88 \pm 0.02$ \\
Electricity conductivity (EC) $(\mathrm{mS} / \mathrm{cm})$ & $1.92 \pm 0.064$ & $0.11 \pm 0.004$ & $0.57 \pm 0.04$ \\
Cationexchange capcity (CEC) $(\mathrm{mmol} / \mathrm{kg})$ & $142.52 \pm 3.48$ & $30.00 \pm 13.00$ & $79.59 \pm 2.06$ \\
Organic matter $(\mathrm{g} / \mathrm{kg})$ & $392 \pm 12$ & $17.87 \pm 0.46$ & $3.82 \pm 0.45$ \\
Total nitrogen $(\mathrm{TN})(\mathrm{g} / \mathrm{kg})$ & $19.37 \pm 2.53$ & $0.15 \pm 0.05$ & $0.007 \pm 0.001$ \\
Total phosphorus $(\mathrm{TP})(\mathrm{g} / \mathrm{kg})$ & $17.14 \pm 1.87$ & $0.35 \pm 0.04$ & $1.51 \pm 0.21$ \\
Total potassium $(\mathrm{TK})(\mathrm{g} / \mathrm{kg})$ & $5.23 \pm 1.34$ & $5.24 \pm 1.06$ & $7.34 \pm 1.26$ \\
$\mathrm{Cu}(\mathrm{mg} / \mathrm{kg})$ & $92.50 \pm 13.79$ & $13.88 \pm 3.42$ & $18.8 \pm 1.45$ \\
$\mathrm{Ni}(\mathrm{mg} / \mathrm{kg})$ & $50.20 \pm 7.92$ & $16.74 \pm 1.99$ & $13.83 \pm 2.57$ \\
$\mathrm{~Pb}(\mathrm{mg} / \mathrm{kg})$ & $42.70 \pm 5.37$ & $7.28 \pm 1.17$ & $15.53 \pm 3.11$ \\
$\mathrm{Zn}(\mathrm{mg} / \mathrm{kg})$ & $1901.00 \pm 36.00$ & $76.99 \pm 6.35$ & $57.09 \pm 5.24$ \\
\hline
\end{tabular}

The EC values of the sewage sludge and fly ash were $1.92 \pm 0.064 \mathrm{mS} / \mathrm{cm}$ and $0.57 \mathrm{mS} \pm 0.04 / \mathrm{cm}$, respectively, which were much higher than that of the brown soil $(0.11 \pm 0.004 \mathrm{mS} / \mathrm{cm})$. Their land application would increase the EC of the soil and was undesirable for plant growth. But, the EC values of the two components were both less than $2 \mathrm{mS} / \mathrm{cm}$, meeting the requirements for the EC level in the Chinese national standard "Disposal of sludge from municipal wastewater treatment plant-Quality of sludge used in gardens or parks" (GB/T23486-2009).

The CEC values of the sewage sludge and fly ash were $142.52 \pm 3.48 \mathrm{mmol} / \mathrm{kg}$ and 79.59 $\pm 2.06 \mathrm{mmol} / \mathrm{kg}$, respectively. The higher CEC value meant better buffering capacity and moisture-holding capacity. Thus, their addition would help to improve the soil properties.

The effect of the sewage sludge and fly ash on the chemical properties of the soil depended on their composition. The contents of the OM, TN, and TP in the sewage sludge were 21.9, 129.1, and 49.0 times those in the brown soil, respectively. The TK content in the sewage sludge $(5.23 \pm 1.34 \mathrm{~g} / \mathrm{kg})$ was similar to that of the brown soil. The high nutrient contents could provide essential OM, N, and $P$ for plant growth. Applying the appropriate amount of sludge to the soil can effectively improve the chemical properties of the soil and make full use of the effective nutrients in sewage sludge. Thus, the land application of sewage sludge has been considered to be an effective method for its treatment and disposal $[10,43,44]$. The contents of the TP and TK in the fly ash were $1.51 \pm 0.21 \mathrm{~g} / \mathrm{kg}$, and 7.34 $\pm 1.26 \mathrm{~g} / \mathrm{kg}$, respectively. Both of the values were higher than those in the brown soil, while the contents of the $\mathrm{OM}$ and TN in the fly ash were in negligible quantities. At the same time, the fly ash was reported to contain not only some macro-nutrients ( $\mathrm{Ca}, \mathrm{Mg}$, and $\mathrm{S}$ ), but also some micro-nutrients $(\mathrm{Cu}, \mathrm{Zn}, \mathrm{Mn}$, and Fe), which were essential to plant growth $[20,45,46]$. Because of the contrasting and complimentary nutrient contents of fly ash and sewage sludge, their cooperation could provide more benefits in increasing soil fertility and improving the soil properties than either the fly ash or the sewage sludge alone.

High concentrations of heavy metals in the soil might influence the microflora and inhibit the activity of the enzymes in the soil. Thus, the presence of heavy metals in sewage sludge has restricted its land application. In order to reduce the environmental risk, many countries have formulated national standards limiting heavy metals in sewage sludge for land application uses. The contents of $\mathrm{Cu}, \mathrm{Ni}$, $\mathrm{Pb}$, and $\mathrm{Zn}$ in the sewage sludge were $92.50 \mathrm{mg} / \mathrm{kg}, 50.20 \mathrm{mg} / \mathrm{kg}, 42.70 \mathrm{mg} / \mathrm{kg}$, and $1901.00 \mathrm{mg} / \mathrm{kg}$, respectively, which were below the limits of GB/T23486-2009. Thus, the results met the national standards for land application uses. In particular, the addition of fly ash could increase the $\mathrm{pH}$ value and form the precipitation in a metal hydroxide form. Therefore, the cooperation of the two components may not only improve the physico-chemical properties of the soil, but also reduce the bioavailability of the heavy metals in sewage sludge. 


\subsection{Immobilization of the Fly Ash on the Heavy Metals in the Sewage Sludge}

The speciation of heavy metals is a more important factor in determining the mobility, bioavailability, and eco-toxicity of a product than the total concentrations of heavy metals. The bioavailability and eco-toxicity of the heavy metals were significantly reduced as their mobile and bioavailable fractions were transformed into the relatively stable fractions [47]. The immobilization effect of the fly ash on the heavy metals in sewage sludge is shown in Figure 2.

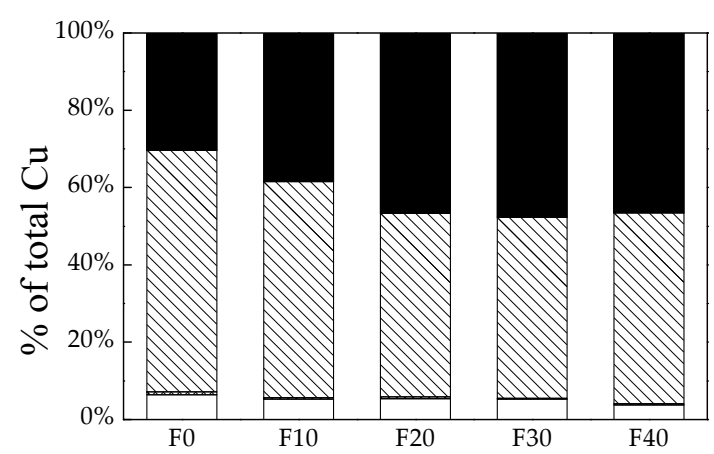

$(\mathrm{Cu})$

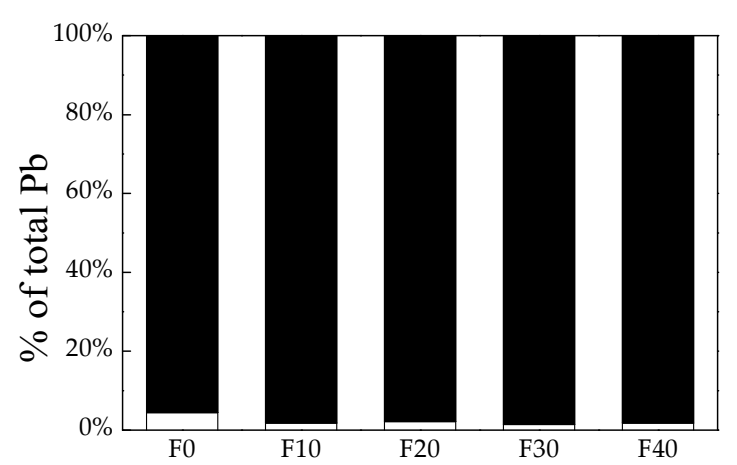

$(\mathrm{Pb})$
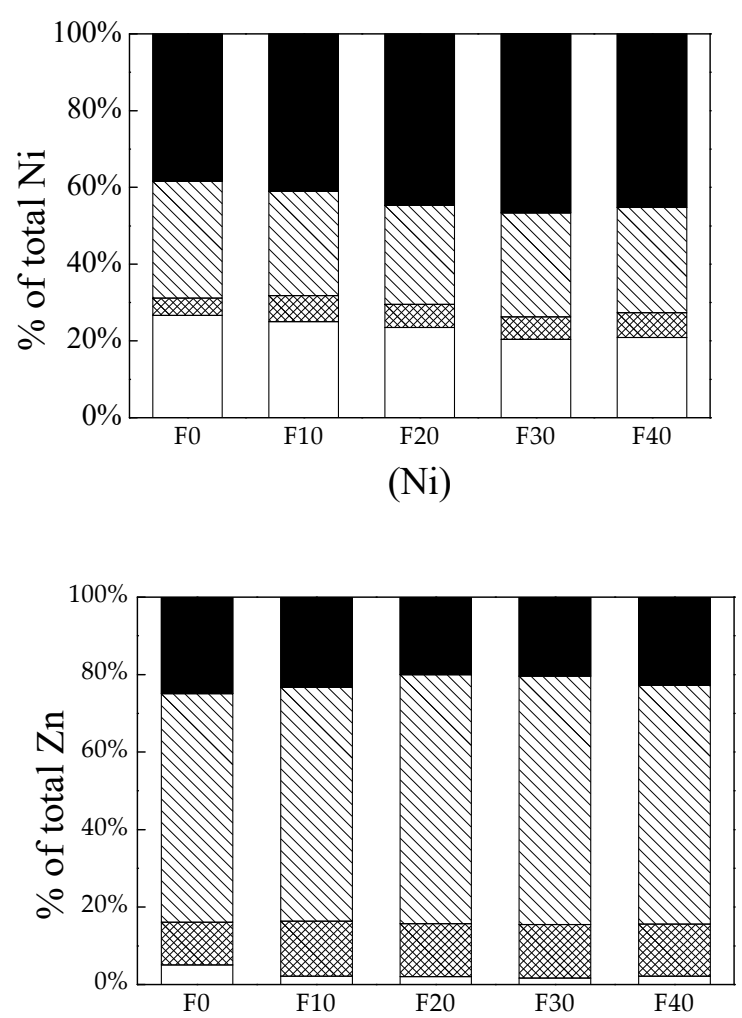

$(\mathrm{Zn})$

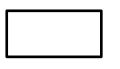

exchangeable fraction reducible fraction

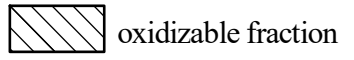

residual fraction

Figure 2. Passivation effect of the fly ash on the heavy metals in the sewage sludge.

$\mathrm{Cu}$ was mainly in the residual fraction and the oxidizable fraction in the sewage sludge. The residual $\mathrm{Cu}$ increased after the addition of the fly ash. When the added amount of fly ash was $20 \%$, the residual $\mathrm{Cu}$ increased from $30.29 \%$ to $47.68 \%$, and the oxidizable fraction decreased from $62.58 \%$ to $47.50 \%$. The decreased oxidizable $\mathrm{Cu}$ was mainly converted into residual $\mathrm{Cu}$. As the fly ash addition further increased, the residual $\mathrm{Cu}$ and oxidizable $\mathrm{Cu}$ changed little, while the exchangeable fraction continued to decrease. When the addition of the fly ash reached $40 \%$, the proportion of the exchangeable $\mathrm{Cu}$ reduced to $3.77 \%$ and was principally converted into oxidizable $\mathrm{Cu}$.

$\mathrm{Ni}$ was mostly in the exchangeable state, the oxidizable state, and the residual state. The residual $\mathrm{Ni}$ increased from $38.34 \%$ to $45.67 \%$, and the exchangeable Ni reduced from $26.65 \%$ to $23.51 \%$ when the addition of the fly ash was $20 \%$. The exchangeable Ni continued to decrease with the increasing fly ash addition. When the added fly ash increased to $40 \%$, the ratio of the exchangeable Ni decreased to $20.87 \%$.

The exchangeable $\mathrm{Pb}$ and residual $\mathrm{Pb}$ in the sewage sludge were $4.42 \%$ and $95.58 \%$, respectively. The reducible $\mathrm{Pb}$ and oxidizable $\mathrm{Pb}$ were both lower than the detection limit. The exchangeable $\mathrm{Pb}$ reduced from $4.44 \%$ to $1.77 \%$ and the residual $\mathrm{Pb}$ increased from $95.58 \%$ to $98.23 \%$ when the addition 
of the fly ash was $10 \%$. Even as the addition of the fly ash continued to increase, the residual $\mathrm{Pb}$ increased little. Thus, the suitable addition of fly ash for the $\mathrm{Pb}$ immobilization was $10 \%$.

$\mathrm{Zn}$ mainly presented in the reducible fraction, the oxidizable fraction, and the residual fraction. The exchangeable $\mathrm{Zn}$ reduced with the increase of the addition of the fly ash. The exchangeable $\mathrm{Zn}$ reduced from $5.10 \%$ to $2.16 \%$, and the reducible $\mathrm{Zn}$ increased from $11.04 \%$ to $14.25 \%$ by adding $10 \%$ fly ash. The exchangeable $\mathrm{Zn}$ was converted into reducible $\mathrm{Zn}$, which helped to reduce the mobility of $\mathrm{Zn}$. However, proportion of the residual $\mathrm{Zn}$ was transformed into oxidizable $\mathrm{Zn}$, which was not conducive to $\mathrm{Zn}$ immobilization.

The results indicated that the fly ash showed different passivation effects on the selected heavy metals in the sewage sludge. Good fixation effects on $\mathrm{Cu}$ and $\mathrm{Pb}$ could be obtained by adding the proper amount of fly ash, while the fixation effects on $\mathrm{Ni}$ and $\mathrm{Zn}$ were poor. When the addition of the fly ash was $10-20 \%$, the best fixation effect was obtained.

Fly ash is a heterogeneous mixture, composed of amorphous vitreous and crystal minerals, such as quartz and mullite. It mainly consists of $\mathrm{SiO}_{2}, \mathrm{Al}_{2} \mathrm{O}_{3}, \mathrm{Fe}_{2} \mathrm{O}_{3}, \mathrm{CaO}, \mathrm{MgO}$, and so on. Iron oxides can combine with heavy metals to form an iron-manganese bound state, and alkaline materials such as $\mathrm{CaO}$ and $\mathrm{MgO}$ are beneficial to the formation of the iron-manganese bound fraction and the residual fraction. The addition of fly ash helps to decrease the mobility of the heavy metals in sewage sludge. In this study, the application of the fly ash increased the contents of the residual $\mathrm{Cu}$, the residual $\mathrm{Ni}$, the residual $\mathrm{Pb}$, the reducible $\mathrm{Ni}$, and the reducible $\mathrm{Zn}$, and the exchangeable fractions of the four heavy metals and the oxidizable $\mathrm{Cu}$ fraction deceased. Moreover, the fly ash contained little $\mathrm{OM}$, and its addition led to the reduction of oxidizable $\mathrm{Cu}$ and oxidizable $\mathrm{Ni}$.

Fly ash generally has strong adsorption properties and a large specific surface area, which helps it to form covalent bonds with heavy metals ions [48]. Bian et al. obtained a modified fly ash with a larger specific surface area and a lot of active groups by using a microwave/alkali method. The passivation performances of the modified fly ash on the exchangeable $\mathrm{Cu}$, the reducible $\mathrm{Cu}$, oxidizable $\mathrm{Cu}$, and the residual $\mathrm{Cu}$ were $18.1 \%, 24.48 \%, 33.25 \%$, and $249.19 \%$ higher than the unmodified fly ash, respectively [49]. In this experiment, the specific surface area of the used fly ash was only $2.09 \mathrm{~m}^{2} / \mathrm{g}$, which was similar to that of sewage sludge. This indicated that the immobilization of the fly ash for the selected four heavy metals was mainly due to the formation of precipitation under high $\mathrm{pH}$ conditions and the transforming into the iron-manganese reducible fraction.

\subsection{Immobilization of the TMT on the Heavy Metals in the Sewage Sludge}

TMT is an organic sulfur compound, produced by the reaction of 2,4,6-trithione-1,3,5-triazine in an alkaline solution. Its special sulfur group can form chelate precipitation by combining with heavy metals. Matlock et al. used TMT to form stable precipitation with $\mathrm{Cd}^{2+}, \mathrm{Pb}^{2+}$, and $\mathrm{Zn}^{2+}$, and no decomposition products were detected in the leached solid residues [50]. Thus, TMT has been widely used in the treatment of wastewater containing heavy metals [51,52]. The immobilization effect of the TMT on the heavy metals in the sewage sludge is shown in Figure 3.

The exchangeable $\mathrm{Cu}$ and the oxidizable $\mathrm{Cu}$ decreased and were transformed into residual $\mathrm{Cu}$ by adding the TMT. The residual $\mathrm{Cu}$ increased from $30.29 \%$ to $38.40 \%$ when $0.4 \%$ TMT was added. The content of the reducible $\mathrm{Cu}$ changed little by increasing the addition of the TMT. When the TMT addition exceeded $0.4 \%$, its immobilization effect on $\mathrm{Cu}$ was not be enhanced. Thus, the optimum dosage of the TMT for the $\mathrm{Cu}$ immobilization was $0.4 \%$.

The TMT addition decreased the exchangeable $\mathrm{Ni}$ and the reducible $\mathrm{Ni}$, while the residual $\mathrm{Ni}$ increased little. The exchangeable $\mathrm{Ni}$ and the reducible $\mathrm{Ni}$ was transformed into oxidizable $\mathrm{Ni}$. The oxidizable Ni increased from $30.55 \%$ to $40.46 \%$ when $0.4 \%$ TMT was added. 

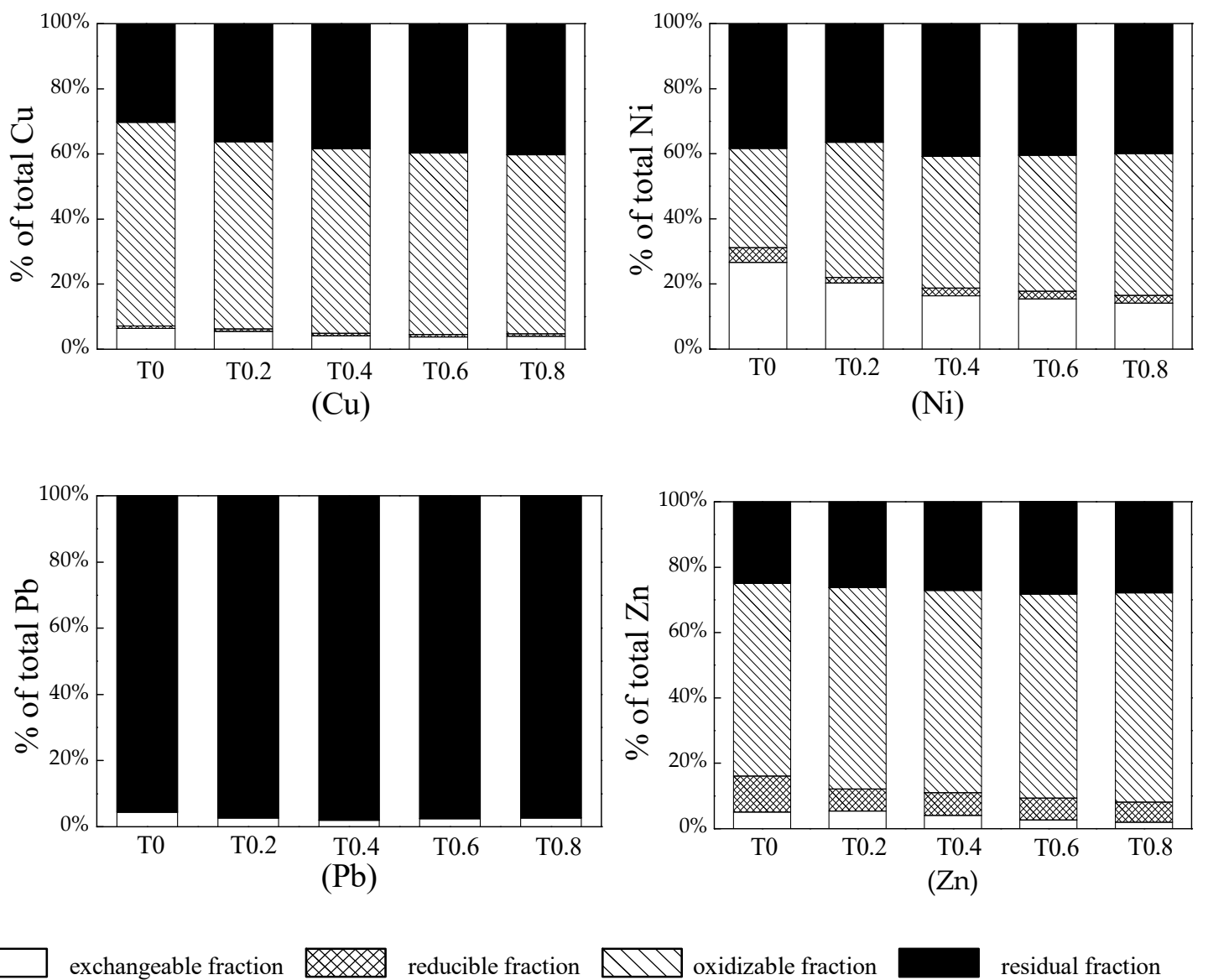

Figure 3. Passivation effect of the TMT on the heavy metals in the sewage sludge.

The exchangeable $\mathrm{Pb}$ reduced from $4.42 \%$ to $1.99 \%$, and the residual $\mathrm{Pb}$ increased from $95.58 \%$ to $98.01 \%$ when the TMT addition was $0.4 \%$. The immobilization effect of the TMT on Pb was similar to that of the fly ash.

The exchangeable $\mathrm{Zn}$ and the reducible $\mathrm{Zn}$ reduced, while the residual $\mathrm{Zn}$ and the oxidizable $\mathrm{Zn}$ increased by adding the TMT. When the TMT addition exceeded $0.6 \%$, there was no obvious enhancement on the $\mathrm{Zn}$ immobilization.

By adding $0.6 \% \mathrm{TMT}$, the residual $\mathrm{Cu}$, the oxidizable $\mathrm{Ni}$, and the oxidizable $\mathrm{Zn}$ increased $31.07 \%$, $36.69 \%$, and $9.33 \%$, respectively, and the exchangeable $\mathrm{Cu}$, the exchangeable $\mathrm{Ni}$, the exchangeable $\mathrm{Pb}$, and the exchangeable $\mathrm{Zn}$ reduced by $41.10 \%, 42.07 \%, 45.07 \%$, and $48.02 \%$, respectively. Based on the comprehensive immobilizing effect of the TMT on the selected four heavy metals, the optimum dosage of the TMT was determined to be $0.4-0.6 \%$. The immobilization effect of the TMT on Cu was obvious. The exchangeable $\mathrm{Cu}$ and the oxidizable $\mathrm{Cu}$ were transformed into residual $\mathrm{Cu}$, which was consistent with the result of Pan et al. [53]. However, its immobilization effect on Ni and Zn was not satisfactory, mainly due to the conversion of the exchangeable fraction and the reducible fraction to an oxidizable fraction rather than the residual state.

\subsection{Synergistic Passivation of the Fly Ash and TMT}

\subsubsection{Synergistic Passivation Effect on the Heavy Metals}

The addition of the fly ash increased the $\mathrm{pH}$ value and helped to form insoluble precipitation, while the TMT immobilized the heavy metals by forming chelate precipitation. Their synergistic passivation effect on the heavy metals is shown in Table 3. The $\Delta$ residual fractions of $\mathrm{Cu}, \mathrm{Ni}, \mathrm{and} \mathrm{Pb}$ in F20T0.5 were $2.56 \%, 1.88 \%$, and $0.4 \%$ higher than those in F20, respectively. The $\Delta$ exchangeable 
fractions of $\mathrm{Cu}, \mathrm{Ni}, \mathrm{Pb}$, and $\mathrm{Zn}$ in F20T0.5 were $2.18 \%, 9.5 \%, 0.4 \%$, and $0.57 \%$ higher than those in F20, respectively. These results indicated that the passivation effects of the TMT + fly ash on $\mathrm{Cu}, \mathrm{Pb}, \mathrm{Ni}$, and $\mathrm{Zn}$ were better than those of the fly ash alone. The $\Delta$ residual fractions and $\Delta$ exchangeable fractions of $\mathrm{Cu}, \mathrm{Ni}$, and $\mathrm{Pb}$ were positive, indicating that good fixation for $\mathrm{Cu}, \mathrm{Ni}$, and $\mathrm{Pb}$ could be obtained by the fly ash and the fly ash + TMT. The $\Delta$ residual fraction of $Z n$ was negative, showing that the passivation effect on $\mathrm{Zn}$ was not satisfactory. Further research on $\mathrm{Zn}$ fixation must be carried out in the future.

Table 3. Synergistic passivation effect of fly ash + TMT on the heavy metals.

\begin{tabular}{ccccccccc}
\hline \multirow{2}{*}{ Samples } & \multicolumn{3}{c}{$\Delta$ Residual Fraction } & \multicolumn{4}{c}{$\Delta$ Exchangeable Fraction } \\
\cline { 2 - 9 } & $\mathbf{C u}$ & $\mathbf{N i}$ & $\mathbf{P b}$ & $\mathbf{Z n}$ & $\mathbf{C u}$ & $\mathbf{N i}$ & $\mathbf{P b}$ & $\mathbf{Z n}$ \\
\hline F20 & 16.39 & 7.34 & 2.24 & -4.94 & 0.99 & 3.14 & 2.24 & 3.01 \\
F20T0.5 & 18.95 & 9.22 & 2.64 & -3.66 & 3.17 & 12.64 & 2.64 & 3.58 \\
\hline
\end{tabular}

F20: sewage sludge treated by $20 \%$ fly ash; F20T0.5: sewage sludge treated by $20 \%$ fly ash and by $0.5 \%$ TMT.

\subsubsection{Effect of the Sewage Sludge on the Ryegrass Growth}

The effects of the three treatments on ryegrass growth are shown in Figure 4. The application of sewage sludge significantly increased the plant height, the number of tillers, the chlorophyll content, and the biomass of the ryegrass over the control treatment. The respective increases of $172 \%$ and $377 \%$ in plant height and $215 \%$ and $380 \%$ in the number of tillers were observed in the USS treatment and the SSS treatment, respectively. The fresh weight increased from $70.98 \mathrm{mg} / \mathrm{m}^{2}$ to $786.17 \mathrm{mg} / \mathrm{m}^{2}$ in the USS treatment and $2349.25 \mathrm{mg} / \mathrm{m}^{2}$ in the SSS treatment, respectively. The dry weight increased from $15.35 \mathrm{mg} / \mathrm{m}^{2}$ to $118.44 \mathrm{mg} / \mathrm{m}^{2}$ in the USS treatment and $291.27 \mathrm{mg} / \mathrm{m}^{2}$ in the SSS treatment, respectively. These increases were due to the supply of OM and the release of $\mathrm{N}, \mathrm{P}$, and micronutrients from the sewage sludge. Many investigators have reported a substantial increase in plant growth and biomass production upon the addition of sewage sludge. Latare reported the same result-that the application of sewage sludge increased the plant height, the number of tillers, and the accumulated aboveground dry matter [6]. Tamrabet et al. indicated that $30 \mathrm{t} / \mathrm{ha}$ of sewage sludge was as efficient as $66 \mathrm{~kg} / \mathrm{ha}$ of mineral nitrogen [54].
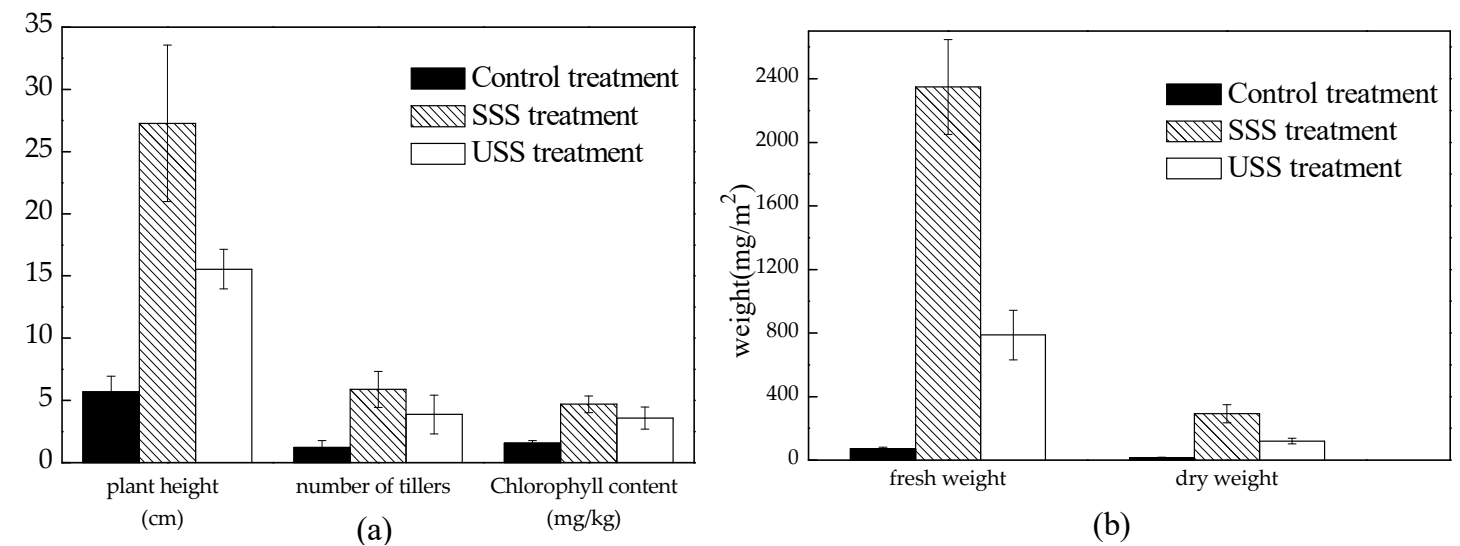

(b)

Figure 4. The effects of sewage sludge on ryegrass growth. (a) the effect on the plant height, the number of tillers, and the chlorophyll content; and (b) the effect on fresh weight and dry weight.

The present study indicated that the addition of sewage sludge also increased the chlorophyll content. Chlorophyll is the molecule that performs photosynthesis in the chloroplasts of green plants. Changes in chlorophyll content could occur as a result of nutrient deficiencies or exposure to environmental stress [55]. Bilgili and Acikgoz pointed out that turf color and quality are associated with $\mathrm{N}$ fertility treatments and that increasing nitrogen significantly enhanced the color and quality ratings of several turfs [56]. The chlorophyll content in the control treatment was the lowest among 
the three treatments, which was mainly attributed to the low content of $\mathrm{N}$ in the brown soil. The high chlorophyll contents in the USS and SSS treatments were mainly ascribed to the supplement of N nutrient from the sewage sludge.

The adverse effect of the heavy metals in the sewage sludge on the ryegrass growth was alleviated by the passivation of the fly ash and TMT, which led to the higher levels of plant production and chlorophyll content in the SSS treatment than in the USS treatment. The plant growth, number of tillers, chlorophyll content, fresh weight, and dry weight in the SSS treatment increased $77.6 \%, 52.4 \%$, $30.6 \%, 199 \%$, and $146 \%$, respectively. These results were indicative of the fertilizer effect of the addition of the sewage sludge on the ryegrass growth, as well as the stress of the heavy metals on the ryegrass growth with the addition of $20 \%$ sewage sludge.

\subsection{Passivation Mechanism of the Fly Ash and TMT on the Heavy Metals}

Fly ash mainly consists of $\mathrm{SiO}_{2}, \mathrm{Al}_{2} \mathrm{O}_{3}, \mathrm{Fe}_{2} \mathrm{O}_{3}, \mathrm{CaO}, \mathrm{MgO}$, and so on. The alkaline materials, such as $\mathrm{CaO}$ and $\mathrm{MgO}$, are beneficial to the formation of the iron-manganese bound state and the residual state, and iron oxides can combine with heavy metals to form the iron-manganese bound state. The $\mathrm{pH}$ value of the sewage sludge immobilized by the fly ash increased, while the EC decreased with the increasing addition of the fly ash (Figure 5). The $\mathrm{pH}$ value of the fly ash was 10.88, which was far higher than that of the sewage sludge (6.89). The high $\mathrm{pH}$ was beneficial for the heavy metals to form insoluble precipitation, which transformed part of the heavy metal ions into the residual fraction. The decrease of the EC was partly due to the addition of the fly ash with low EC into the sewage sludge. On the other hand, the precipitation of the exchangeable metals was another reason for the reduction of the EC. A similar result indicated by Zhang et al. demonstrated that the treatment with fly ash stabilized $\mathrm{Pb}$ and $\mathrm{Cd}$ effectively [57].
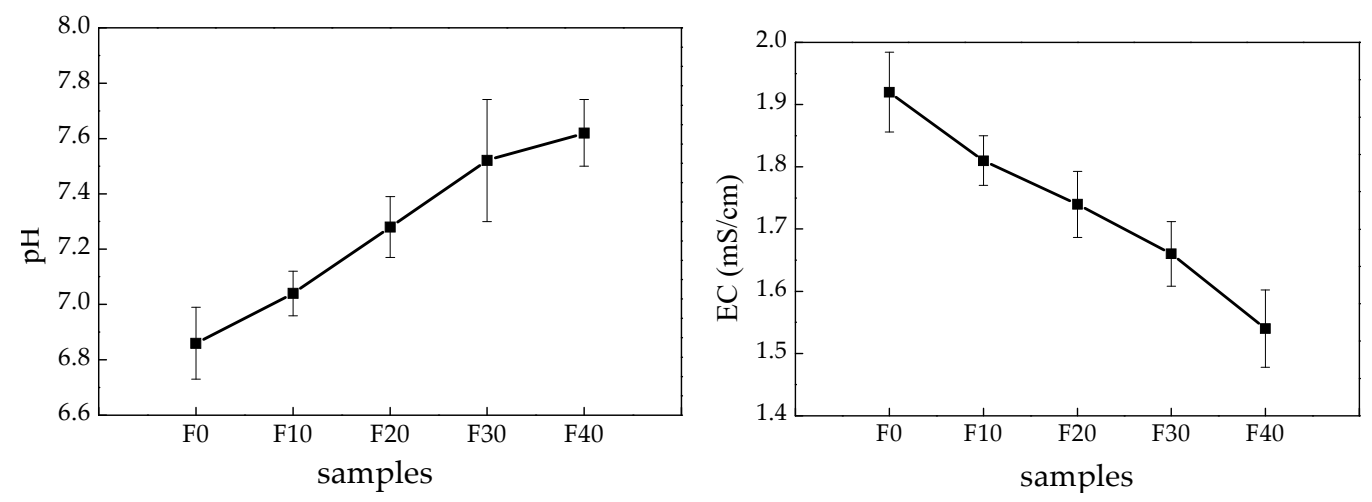

Figure 5. Effect of the addition of fly ash on the $\mathrm{pH}$ and EC.

The XRD patterns of the fly ash and the treated and untreated sewage sludge were recorded in Figure 6 and analyzed by Jade software. The results showed that the main crystal phases in the fly ash were $\mathrm{SiO}_{2}, \mathrm{Al}_{2} \mathrm{O}_{3}, \mathrm{Fe}_{2} \mathrm{O}_{3}, \mathrm{CaCO}_{3}$, and $\mathrm{CaO}$ (Figure 6a). The sewage sludge was a multi-phase system consisting of many kinds of organic and inorganic substances, many of which existed in amorphous form. Its pattern consisted of strong intensity peaks corresponding to $\mathrm{SiO}_{2}$ and weak peaks of $\mathrm{Pb}\left(\mathrm{NO}_{3}\right)_{2}, \mathrm{CuCl}_{2} \cdot 2 \mathrm{H}_{2} \mathrm{O}, \mathrm{Ca}_{2} \mathrm{Cu}\left(\mathrm{SO}_{4}\right)_{3} \cdot 2 \mathrm{H}_{2} \mathrm{O}, \mathrm{CaZn}\left(\mathrm{CO}_{3}\right)_{2}, \mathrm{Zn}\left(\mathrm{NO}_{3}\right)_{2} \cdot 2 \mathrm{H}_{2} \mathrm{O}, \mathrm{NiCl}_{2} \cdot 4 \mathrm{H}_{2} \mathrm{O}$, and $\mathrm{NiSO}_{4}$ (Figure $6 \mathrm{~b}$ ). The addition of the fly ash was beneficial to the formation of the insoluble basic salts (such as $\mathrm{Pb}_{3}\left(\mathrm{NO}_{3}\right)(\mathrm{OH})_{5}, \mathrm{Cu}_{3}\left(\mathrm{SO}_{4}\right)(\mathrm{OH})_{4}, \mathrm{Zn}_{5}\left(\mathrm{NO}_{3}\right)_{2}(\mathrm{OH})_{8} \cdot 2 \mathrm{H}_{2} \mathrm{O}, \mathrm{Cu}_{2} \mathrm{Cl}(\mathrm{OH})_{3}, \mathrm{Ni}_{2} \mathrm{Cl}(\mathrm{OH})_{3}$, and $\left.\mathrm{CaZn}\left(\mathrm{CO}_{3}\right)(\mathrm{OH})_{2}\right)$ and metal hydroxides such as $\mathrm{Ni}(\mathrm{OH})_{2}$ and $\mathrm{ZnSO}_{4} \cdot 2 \mathrm{Zn}(\mathrm{OH})_{2}$ (Figure 6c). The reduction of the exchangeable fraction in the treated sewage sludge might be attributed to the transformation of the heavy metals from soluble salts to insoluble basic salts. Masto et al. indicated that the $\mathrm{pH}$ increase caused the precipitation of heavy metals in the treated sewage sludge, which was the most influential factor that caused the reduction in diethylenetriaminepentaacetic acid (DTPA)-extractable $\mathrm{Zn}, \mathrm{Co}$, and $\mathrm{Cu}[58]$. 


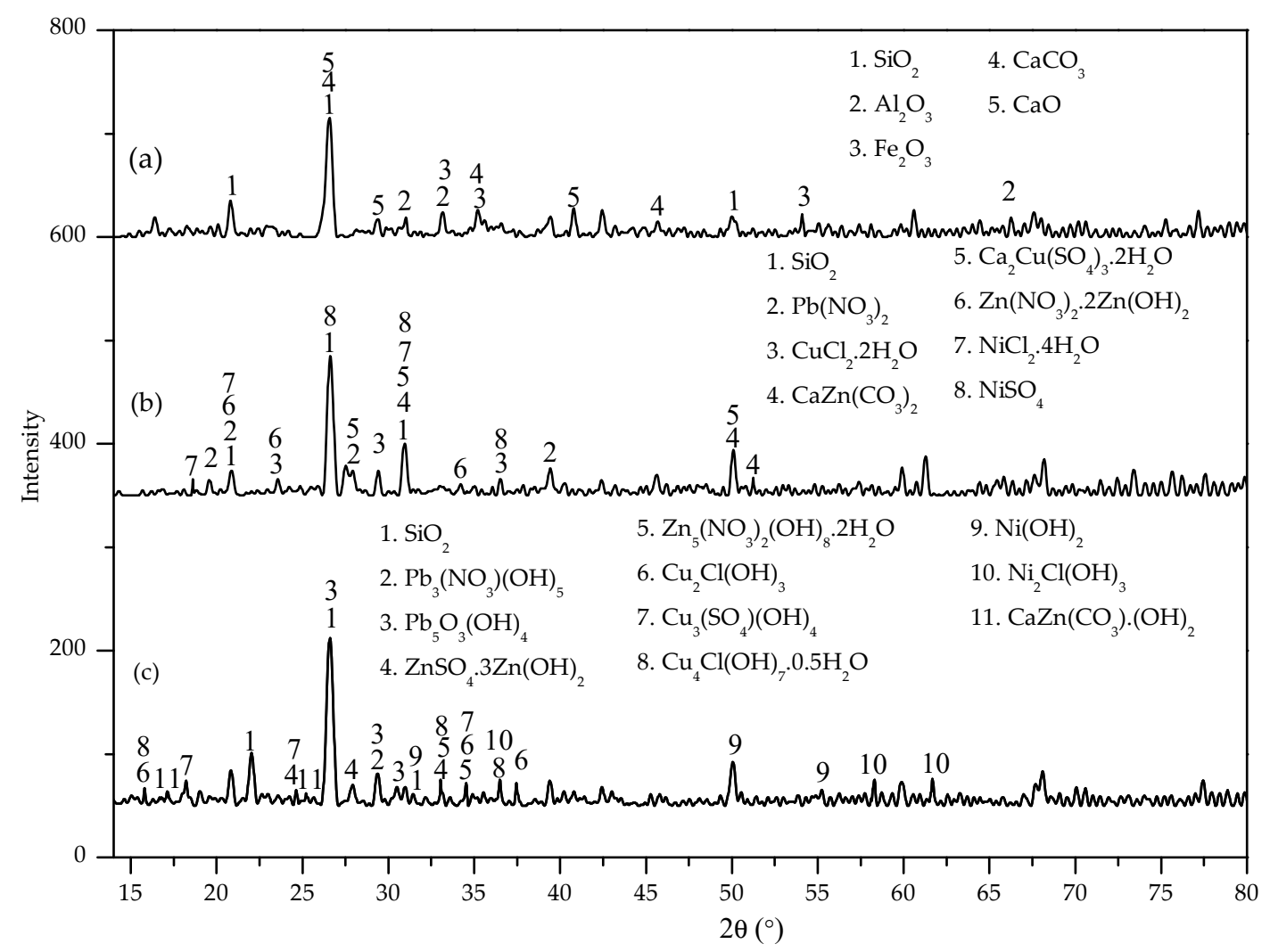

(a) FA; (b) sewage sludge; (c) sewage sludge treated by FA

Figure 6. XRD diagrams of the fly ash and the sewage sludge.

In addition, fly ash generally possesses many desirable capabilities, such as adsorption, ion exchange, coagulability, and precipitability and shows high performance with respect to heavy metal passivation. $\mathrm{Xu}$ et al. indicated that high specific surface areas and small pore diameters were beneficial for removing mercury efficiently [48]. The CEC of the used fly ash was as high as $79.59 \pm$ $2.06 \mathrm{mmol} / \mathrm{kg}$, and its specific surface area was only $2.09 \mathrm{~m}^{2} / \mathrm{g}$, which was similar to that of the sewage sludge $\left(2.03 \mathrm{~m}^{2} / \mathrm{g}\right)$. This indicated that the immobilization performance of the fly ash was mainly due to the formation of precipitation under high $\mathrm{pH}$ conditions and ion exchange rather than adsorption.

The TMT was added into the sewage sludge immobilized by the fly ash to improve the immobilization performance. Its special sulfur group could combine with heavy metals by chelate precipitation. In aqueous solutions, the TMT existed mainly in four forms: $\left(\mathrm{C}_{3} \mathrm{~N}_{3} \mathrm{~S}_{3}\right)^{3-}$, $\left(\mathrm{HC}_{3} \mathrm{~N}_{3} \mathrm{~S}_{3}\right)^{2-}$, $\left(\mathrm{H}_{2} \mathrm{C}_{3} \mathrm{~N}_{3} \mathrm{~S}_{3}\right)^{-}$, and $\left(\mathrm{H}_{3} \mathrm{C}_{3} \mathrm{~N}_{3} \mathrm{~S}_{3}\right)^{0}$. The main form was determined by the $\mathrm{pH}$ value of the solution. In the SSS treatment, the $\mathrm{pH}$ value was 7.28 and $\left(\mathrm{H}_{2} \mathrm{C}_{3} \mathrm{~N}_{3} \mathrm{~S}_{3}\right)^{-}$was the main form reacting with the heavy metal ions and forming chelating precipitates according to Equation (1) and Equation (2).

$$
\begin{gathered}
\left(\mathrm{H}_{2} \mathrm{C}_{3} \mathrm{~N}_{3} \mathrm{~S}_{3}\right)^{-}+\mathrm{M}^{+} \rightarrow \mathrm{MH}_{2} \mathrm{C}_{3} \mathrm{~N}_{3} \mathrm{~S}_{3} \downarrow . \\
2\left(\mathrm{H}_{2} \mathrm{C}_{3} \mathrm{~N}_{3} \mathrm{~S}_{3}\right)^{-}+\mathrm{M}^{2+} \rightarrow M\left(\mathrm{H}_{2} \mathrm{C}_{3} \mathrm{~N}_{3} \mathrm{~S}_{3}\right)_{2} \downarrow .
\end{gathered}
$$

Figure 7 shows the SEM images of the brown soil, the sewage sludge, the fly ash, and the immobilized sewage sludge. The brown soil sample showed a single granular structure rather than a cluster structure (Figure 7a), meaning the degree of the brown soil agglomeration was very low, which might have been due to the low content of OM. Its OM content was only $17.87 \mathrm{~g} / \mathrm{kg}$, which was lower than the average OM content in Chinese plough layer $(24.65 \mathrm{~g} / \mathrm{kg}$ ) [59]. The low content of OM indicated that the soil fertility in the study area was low, and the addition of OM would help to improve this condition. Figure $7 \mathrm{~b}$ shows that the sewage sludge particles were dispersive, with 
irregular structures, such as lumps and flakes. Their sizes varied greatly. During the air drying process of the dewatered sludge, with the migration and diffusion of the inner water, the sludge produced cracks, shrinkage, and agglomeration, and its hardness increased [60]. The air-dried sludge was crushed by mechanical force to obtain irregular particles that had folded surfaces. The fly ash particles were mainly spherical in shape and consisted of solid spheres, hollow microspheres, irregular-shaped debris, and porous unburnt carbon (Figure 7c). Its compact surface resulted in a low specific surface area $\left(2.09 \mathrm{~m}^{2} / \mathrm{g}\right)$ and was not conducive to the passivation of heavy metals through adsorption. The SEM images of the sewage sludge treated by the fly ash showed that the fly ash was mixed loosely with the sewage sludge (Figure $7(\mathrm{~d} 1, \mathrm{~d} 2)$ ). In the sewage sludge treated by the fly ash + TMT (Figure $7(\mathrm{e} 1, \mathrm{e} 2))$, the fly ash particles were wrapped by sludge particles, and they were fully contacted and formed some more compact microstructures, which were conducive to ion exchange between the heavy metals in the sewage sludge and in the fly ash. Thus, the TMT not only formed chelating precipitates with the heavy metals but could also help the treated sewage sludge to form a dense structure, which could improve the immobilization of the heavy metals. The synergistic effect of the fly ash and TMT could improve the passivation effect on the heavy metals in the sewage sludge.
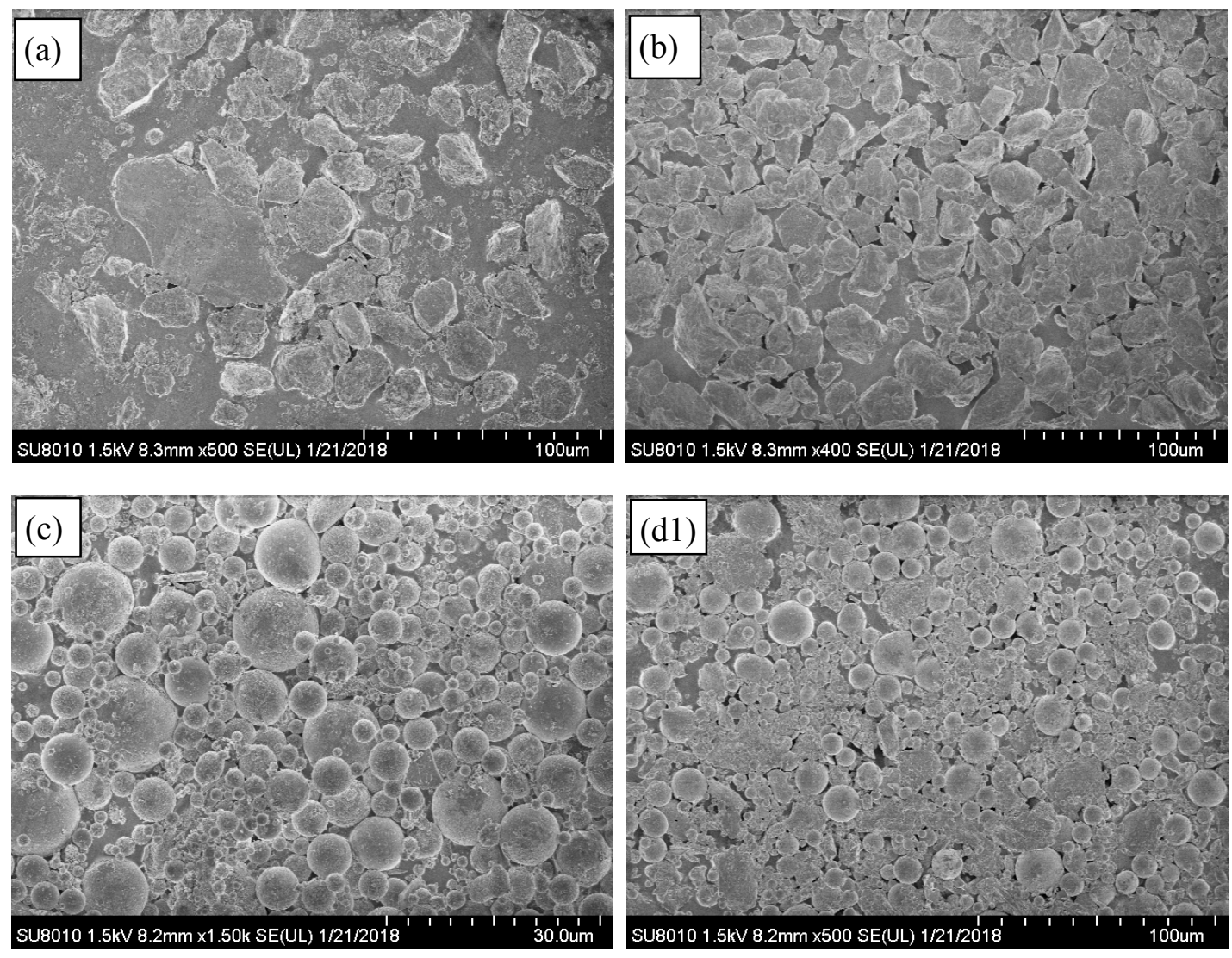

Figure 7. Cont. 

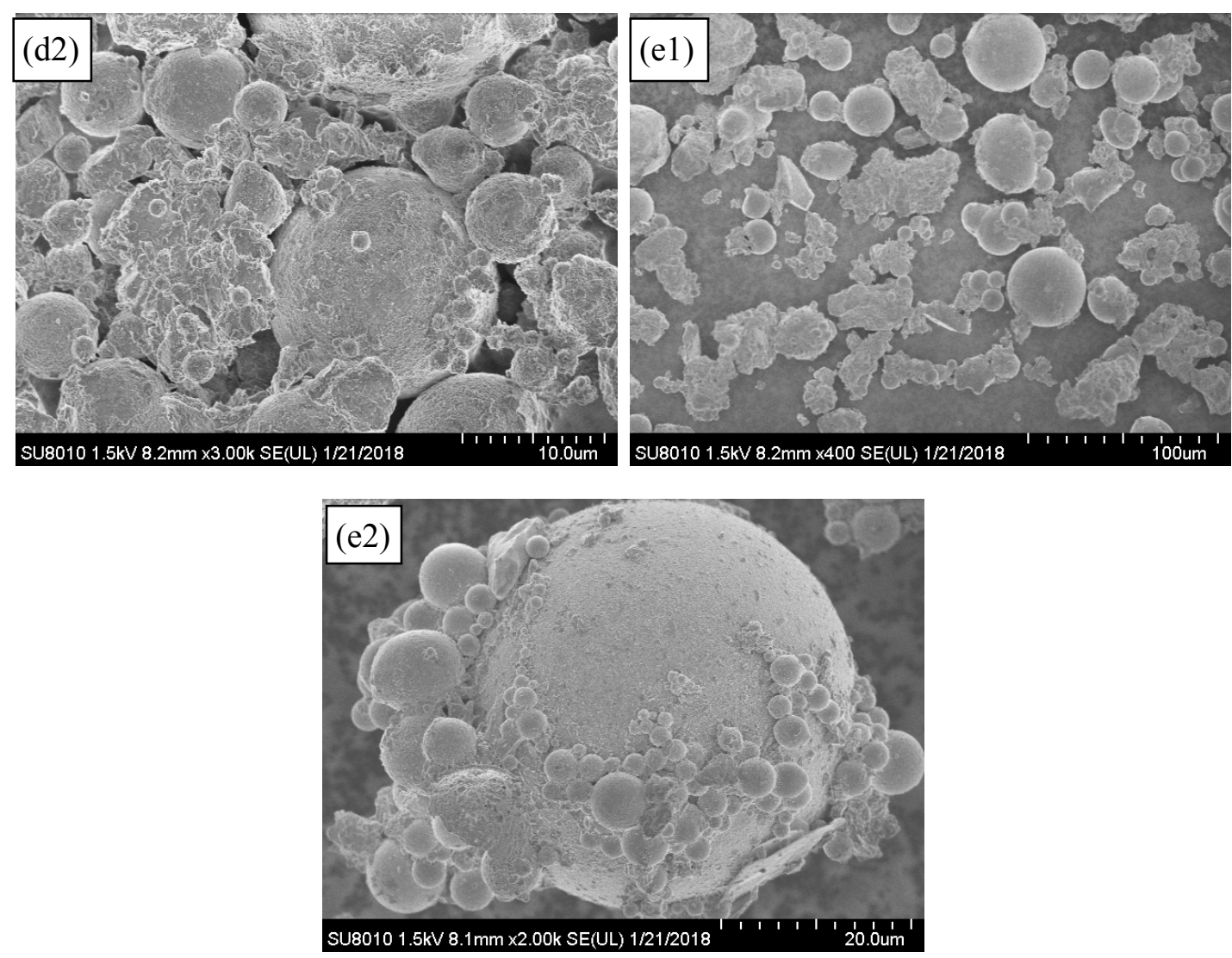

Figure 7. SEM images of the soil, the fly ash, and the sewage sludge. (a) the brown soil; (b) the sewage sludge; (c) the fly ash; (d1) and (d2) the sewage sludge treated by the fly ash; and (e1) and (e2) the sewage sludge treated by the fly ash + TMT.

\section{Conclusions}

TMT and fly ash were synergistically used to passivate heavy metals in sewage sludge in order to improve the fixation effect, which would help to solve the obstacle restraining the land application of sewage sludge and to realize the resource utilization of fly ash.

The selected dewatered sewage sludge was rich in $\mathrm{OM}, \mathrm{N}$, and $\mathrm{P}$, which satisfied the nutritional demand of GB/T23486-2009. The contents of the four heavy metals ( $\mathrm{Cu}, \mathrm{Ni}, \mathrm{Zn}$, and $\mathrm{Pb})$ were below the limits of GB/T23486-2009. Fly ash and TMT was used to stabilize the heavy metals in the sewage sludge and showed different passivation effects on the four selected heavy metals. The optimum effect could be gained by adding $10-20 \%$ fly ash or $0.4-0.6 \%$ TMT. Their synergistic passivation of $20 \%$ fly ash $+0.5 \%$ TMT was superior to adding the fly ash alone. The plant height, the tiller number, and the chlorophyll content increased by $172 \%, 215 \%$, and $126 \%$ in USS treatment and by $377 \%, 380 \%$, and $196 \%$ in the SSS treatment, respectively. The fresh weight and dry weight were 6.7 and 10.1 times higher in USS treatment and 32.1 and 18.0 times higher in the SSS treatment, respectively. The adverse effect of the heavy metals in the sewage sludge on the ryegrass growth could be alleviated by the synergistic passivation of fly ash + TMT. The immobilization performance of the used fly ash was mainly due to the formation of precipitation under high $\mathrm{pH}$ conditions and ion exchange, while the effect of TMT was due to chelate precipitation.

Author Contributions: Data curation, S.-H.L., X.-Q.W., and L.-X.L.; Formal analysis, D.-F.W. and X.Z.; Methodology, D.-F.W. and X.-Q.W.; Project administration, X.-Q.W. and X.Z.; Original draft preparation, D.-F.W., S.-H.L., and X.Z.; and Reviewing and editing, D.-F.W., S.-H.L., and X.Z.

Funding: This research was supported by the College Students' Innovation and Entrepreneurship Project from Qilu University of Technology and the Natural Science Foundation of Shandong Province, China (ZR2014JL012). 
Conflicts of Interest: The authors declare no conflicts of interest. The funding sponsors had no role in the design of the study; in the collection, analyses, or interpretation of data; in the writing of the manuscript; or in the decision to publish the results.

\section{References}

1. Chen, H.B.; Xu, L.Q.; Zhang, Y.C.; Cao, B.; Liu, W.J.; Fu, Y.L. A case project for sewage sludge and food waste co-digestion. China Water Wastewater 2018, 34, 79-84.

2. Li, J.; Luo, G.; Gao, J.; Yuan, S.; Du, J.; Wang, Z. Quantitative evaluation of potential ecological risk of heavy metals in sewage sludge from three wastewater treatment plants in main urban area of Wuxi, China. Chem. Ecol. 2015, 31, 235-251. [CrossRef]

3. Leng, L.; Yuan, X.; Huang, H.; Jiang, H.; Chen, X.; Zeng, G. The migration and transformation behavior of heavy metals during the liquefaction process of sewage sludge. Bioresour. Technol. 2014, 167, 144-150. [CrossRef] [PubMed]

4. Alvarenga, P.; Mourinha, C.; Farto, M.; Santos, T.; Palma, P.; Sengo, J.; Morais, M.; Cunha-Queda, C. Sewage sludge, compost and other representative organic wastes as agricultural soil amendments: Benefits versus limiting factors. Waste Manag. 2015, 40, 44-52. [CrossRef] [PubMed]

5. Sharma, B.; Sarkar, A.; Singh, P.; Singh, R.P. Agricultural utilization of biosolids: A review on potential effects on soil and plant grown. Waste Manag. 2017, 64, 117-132. [CrossRef] [PubMed]

6. Latare, A.M.; Kumar, O.; Singh, S.K.; Gupta, A. Direct and residual effect of sewage sludge on yield, heavy metals content and soil fertility under rice-wheat system. Ecol. Eng. 2014, 69, 17-24. [CrossRef]

7. Sieciechowicz, A.; Sadecka, Z.; Myszograj, S.; Włodarczyk-Makuła, M.; Wiśniowska, E.; Turek, A. Occurrence of heavy metals and PAHs in soil and plants after application of sewage sludge to soil. Desalin. Water Treat. 2014, 52, 4014-4026. [CrossRef]

8. Przemysław, K.; Magdalena, K.; Bogusław, B. Immobilization of selected heavy metals in sewage sludge by natural zeolites. Bioresour. Technol. 2008, 99, 5972-5976. [CrossRef]

9. Singh, J.W.; Kalamdhad, A.S. Reduction of heavy metals during composting-A review. Int. J. Environ. Protect. 2012, 2, 36-43. [CrossRef]

10. Zhang, X.; Wang, X.Q.; Wang, D.F. Immobilization of heavy metals in sewage sludge during land application process in China: A review. Sustainability 2017, 9, 2020. [CrossRef]

11. Xu, G.; Shi, X.M. Characteristics and applications of fly ash as a sustainable construction material: A stateof-the art review. Resour. Conserv. Recycl. 2018, 136, 95-109. [CrossRef]

12. Liu, X.J.; Wang, H.; Liu, L.L. Development and utilization of fly ash resources. Inorg. Chem. Ind. 2018, 50, $12-14$.

13. Zhuang, X.Y.; Chen, L.; Komarneni, S.; Zhou, C.H.; Tong, D.S.; Yang, H.M.; Yu, W.H.; Wang, H. Fly ash-based geopolymer: Clean production, properties and applications. J. Clean. Prod. 2016, 125, 253-267. [CrossRef]

14. Rodrigues, P.; Silvestre, J.D.; Flores-Colen, I.; Viegas, C.A.; de Brito, J.; Kurad, R.; Demertzi, M. Methodology for the assessment of the ecotoxicological potential of construction materials. Materials 2017, 10, 649. [CrossRef] [PubMed]

15. Ansari, M.; Aroujalian, A.; Raisi, A.; Dabir, B.; Fathizadeh, M. Preparation and characterization of nano-NaX zeolite by microwave assisted hydrothermal method. Adv. Powder Technol. 2014, 25, 722-727. [CrossRef]

16. Yao, Z.T.; Ji, X.S.; Sarker, P.K.; Tang, J.H.; Ge, L.Q.; Xia, M.S.; Xi, Y.Q. A comprehensive review on the applications of coal fly ash. Earth-Sci. Rev. 2015, 141, 105-121. [CrossRef]

17. Ram, L.C.; Masto, R.E. Fly ash for soil amelioration: A review on the influence of ash blending with inorganic and organic amendments. Earth-Sci. Rev. 2014, 128, 52-74. [CrossRef]

18. Nayak, A.K.; Raja, R.; Rao, K.S.; Shukla, A.K.; Mohanty, S.; Shahid, M.; Tripathi, R.; Panda, B.B.; Bhattacharyya, P.; Kumar, A.; et al. Effect of fly ash application on soil microbial response and heavy metal accumulation in soil and rice plant. Ecotoxicol. Environ. Saf. 2015, 114, 257-262. [CrossRef]

19. Skousen, J.; Yang, J.E.; Lee, J.; Ziemkiewicz, P. Review of fly ash as a soil amendment. Geosyst. Eng. 2013, 16, 249-256. [CrossRef]

20. Shaheen, S.M.; Hooda, P.S.; Tsadilas, C.D. Opportunities and challenges in the use of coal fly ash for soil improvements-A review. J. Environ. Manag. 2014, 145, 249-267. [CrossRef] 
21. Bao, S.D. Soil Agro-Chemistrical Analysis, 3rd ed.; China Agriculture Press: Beijing, China, 2007; pp. 30-34, 39-58, 71-83. ISBN 9787109066441.

22. Veschetti, E.; Maresca, D.; Santarsiero, A.; Ottaviani, M. Sewage sludge microwave digestion procedure optimized by temperature and pressure analysis. Microchem. J. 1998, 59, 246-257. [CrossRef]

23. Tessier, A.; Campbell, P.G.C.; Bisson, M. Sequential extraction procedure for the speciation of particulate trace metals. Anal. Chem. 1979, 51, 844-850. [CrossRef]

24. Rauret, G.; López-Sánchez, J.F.; Sahuquillo, A.; Rubio, R.; Davidson, C.; Ure, A.; Quevauviller, P. Improvement of the BCR three step sequential extraction procedure prior to the certification of new sediment and soil reference materials. J. Environ. Monitor. 1999, 1, 57-61. [CrossRef]

25. Ciba, J.; Zolotajkin, M.; Kluczka, J.; Loska, K.; Cebula, J. Comparison of methods for leaching heavy metals from composts. Waste Manag. 2003, 23, 897-905. [CrossRef]

26. Liu, Q.Q.; Wang, F.F.; Meng, F.P.; Jiang, L.; Li, G.J.; Zhou, R.G. Assessment of metal contamination in estuarine surface sediments from Dongying City, China: Use of a modified ecological risk index. Mar. Pollut. Bull. 2018, 126, 293-303. [CrossRef] [PubMed]

27. Wen, J.; Yi, Y.J.; Zeng, G.M. Effects of modified zeolite on the removal and stabilization of heavy metals in contaminated lake sediment using BCR sequential extraction. J. Environ. Manag. 2016, 178, 63-69. [CrossRef] [PubMed]

28. Seshadri, B.; Bolan, N.S.; Choppala, G.; Kunhikrishnan, A.; Sanderson, P.; Wang, H.; Currie, L.D.; Tsang, D.; OK, Y.S.; Kim, K. Potential value of phosphate compounds in enhancing immobilization and reducing bioavailability of mixed heavy metal contaminants in shooting range soil. Chemosphere 2017, 184, 197-206. [CrossRef] [PubMed]

29. Rodríguez, L.; Ruiz, E.; Alonso-Azcárate, J.; Rincón, J. Heavy metal distribution and chemical speciation in tailings and soils around a Pb-Zn mine in Spain. J. Environ. Manag. 2008, 90, 1106-1116. [CrossRef]

30. He, X.; Zhang, Y.X.; Shen, M.C.; Zeng, G.M.; Zhou, M.C.; Li, M.R. Effect of vermicomposting on concentration and speciation of heavy metals in sewage sludge with additive materials. Bioresour. Technol. 2016, 218, 867-873. [CrossRef]

31. Yuan, X.Z.; Huang, H.J.; Zeng, G.M.; Li, H.; Wang, J.Y.; Zhou, C.F.; Zhu, H.N.; Pei, H.K.; Liu, Z.F.; Liu, Z.T. Total concentrations and chemical speciation of heavy metals in liquefaction residues of sewage sludge. Bioresour. Technol. 2014, 102, 4104-4110. [CrossRef]

32. Luan, J.D.; Chai, M.Y.; Liu, Y.W.; Ke, X. Heavy-metal speciation redistribution in solid phase and potential environmental risk assessment during the conversion of MSW incineration fly ash into molten slag. Environ. Sci. Pollut. Res. 2018, 25, 3793-3801. [CrossRef] [PubMed]

33. Poykio, R.; Nurmesniemi, H.; Dahl, O.; Makela, M. Chemical fractionation method for characterization of biomass-based bottom and fly ash fractions from large-sized power plant of an integrated pulp and paper mill complex. Trans. Nonferrous Met. Soc. China 2014, 24, 588-596. [CrossRef]

34. Nurmesniemi, H.; Pöykiö, R.; Watkins, G.; Dahl, O. Total and extractable heavy metal phosphorous and sulfur concentrations in slaker grits from the causticizing process of a pulp mill for use as a soil amendment. Chem. Speciat. Bioavailab. 2010, 22, 87-97. [CrossRef]

35. Islam, M.S.; Ahmed, M.K.; Raknuzzaman, M.; Habibullah-Al-Mamun, M.; Kundu, G.K. Heavy metals in the industrial sludge and their ecological risk: A case study for a developing country. J. Geochem. Explor. 2017, 172, 41-49. [CrossRef]

36. Mäkelä, M.; Watkins, G.; Pöykiö, R.; Nurmesniemi, H.; Dahl, O. Utilization of steel, pulp and paper industry solid residues in forest soil amendment: Relevant physicochemical properties and heavy metal availability. J. Hazard. Mater. 2012, 207-208, 21-27. [CrossRef] [PubMed]

37. Zhang, C.Y.; Peng, P.G.; Song, J.Z.; Liu, C.S.; Peng, Y.; Lu, P.X. Improved BCR method to analyze the chemical forms of heavy metals in national soil reference materials. J. Ecol. Environ. 2012, 21, 1881-1884.

38. Moćko, A.; Wacławek, W. Three-step extraction procedure for determination of heavy metals availability to vegetables. Anal. Bioanal. Chem. 2004, 380, 813-817. [CrossRef] [PubMed]

39. Ritchie, R.J. Consistent sets of spectrophotometric chlorophyll equations for acetone, methanol and ethanol solvents. Photosynth. Res. 2006, 89, 27-41. [CrossRef]

40. Rakesh, M.; Gabriela, M.; Benjamin, L.; Stephanie, L. Development of a standardized methodology for quantifying total chlorophyll and carotenoids from foliage of hardwood and conifer tree species. Can. J. For. Res. 2009, 39, 849-861. [CrossRef] 
41. Su, D.C.; Wong, J.W.C. Chemical speciation and phytoavailability of $\mathrm{Zn}, \mathrm{Cu}, \mathrm{Ni}$ and $\mathrm{Cd}$ in soil amended with fly ash-stabilized sewage sludge. Environ. Int. 2003, 29, 895-900. [CrossRef]

42. Xu, J.Q.; Yu, R.L.; Dong, X.Y.; Hu, G.R.; Shang, X.S.; Wang, Q.; Li, H.W. Effects of municipal sewage sludge stabilized by fly ash on the growth of Manilagrass and transfer of heavy metals. J. Hazard. Mater. 2012, 217-218, 58-66. [CrossRef] [PubMed]

43. Peña, A.; Mingorance, M.D.; Rossini-Oliva, S. Soil quality improvement by the establishment of a vegetative cover in a mine soil added with composted municipal sewage sludge. J. Geochem. Explor. 2015, 157, 178-183. [CrossRef]

44. Grobelak, A.; Placek, A.; Grosser, A.; Singh, B.R.; Almås, A.R.; Napora, A.; Kacprzak, M. Effects of single sewage sludge application on soil phytoremediation. J. Clean. Prod. 2017, 155, 89-197. [CrossRef]

45. Lopez-Ramon, M.V.; Fontecha-Camara, M.A.; Alvarez-Merino, M.A.; Moreno-Castilla, C. Removal of diuron and amitrol from water under static and amitrol from water under static and dynamic conditions using activated carbon in form of fiber, cloth and grains. Water Res. 2007, 41, 2865-2870. [CrossRef] [PubMed]

46. Pandey, V.C.; Abhilash, P.C.; Upadhyay, R.N.; Tewari, D.D. Application of fly ash on the growth performance and translocation of toxic heavy metals within Cajanus cajan L.: Implication for safe utilization of fly ash for agricultural production. J. Hazard. Mater. 2009, 166, 255-259. [CrossRef] [PubMed]

47. Devi, P.; Saroha, A.K. Risk analysis of pyrolyzed biochar made from paper mill effluent treatment plant sludge for bioavailability and eco-toxicity of heavy metals. Bioresour. Technol. 2014, 162, 308-315. [CrossRef] [PubMed]

48. Xu, W.Q.; Wang, H.R.; Zhu, T.Y.; Kuang, J.Y.; Jing, P.F. Mercury removal from coal combustion flue gas by modified fly ash. J. Environ. Sci. 2013, 25, 393-398. [CrossRef]

49. Bian, J.; Wang, Y.F.; He, J.G.; Yuan, Y.X.; Liu, T.T. Passivation of copper and zinc in sludge by microwave/alkali modified fly ash. China Water Wastewater 2016, 32, 91-95.

50. Matlock, M.M.; Henke, K.R.; Atwood, D.A.; Robertson, D. Aqueous leaching properties and environmental implications of cadmium, lead and zinc trimercaptotriazine (TMT) compounds. Water Res. 2001, 35, 3649-3655. [CrossRef]

51. Henke, K.R.; Robertson, D.; Krepps, M.K.; Atwood, D.A. Chemistry and stability of precipitates from aqueous solutions of 2,4,6-trimercaptotriazine, trisodium salt, nonahydrate (TMT-55) and mercury (II) chloride. Water Res. 2000, 34, 3005-3013. [CrossRef]

52. Decostere, B.; Hogie, J.; Dejans, P.; Van Hulle, S.W.H. Removal of heavy metals occurring in the washing water of flue gas purification. Chem. Eng. J. 2009, 150, 196-203. [CrossRef]

53. Pan, S.W.; Qiu, K.; Sun, T.H.; Zhang, H.B.; Jia, J.P. Application of chelating agents for heavy metals removal from electroplating effluent. Mod. Chem. Ind. 2015, 35, 61-65.

54. Tamrabet, L.; Bouzerzour, H.; Kribaa, M.; Makhlouf, M. The effect of sewage sludge application on durum wheat (Triticum durum). Int. J. Agric. Biol. 2009, 11, 741-745. [CrossRef]

55. Cheng, H.F.; Xu, W.P.; Liu, J.L.; Zhao, Q.J.; He, Y.Q.; Chen, G. Application of composted sewage sludge (CSS) as a soil amendment for turfgrass growth. Ecol. Eng. 2007, 29, 96-104. [CrossRef]

56. Bilgili, U.; Acikgoz, E. Year-round nitrogen fertilization effects on growth and quality of sports turf mixtures. J. Plant Nutr. 2005, 28, 299-307. [CrossRef]

57. Zhang, H.L.; Sun, L.; Sun, T.H. Solubility of ion and trace metals from stabilized sewage sludge by fly ash and alkaline mine tailing. J. Environ. Sci. 2008, 20, 710-716. [CrossRef]

58. Masto, R.E.; Sunar, K.K.; Sengupta, T.; Ram, L.C.; Rout, T.K.; Selvi, V.A.; George, J.; Sinha, A.K. Evaluation of the co-application of fly ash and sewage sludge on soil biological and biochemical quality. Environ. Technol. 2012, 33, 897-905. [CrossRef] [PubMed]

59. Yang, F.; Xu, Y.; Cui, Y.; Meng, Y.D.; Dong, Y.; Li, R.; Ma, Y.B. Variation of soil organic matter content in croplands of China over the last three decades. Acta Pedol. Sin. 2017, 54, 1047-1056. [CrossRef]

60. Li, A.M.; Qu, Y.L.; Yang, Z.X.; Li, Y.D. Surface configuration and moisture transference during sewage sludge drying. J. Chem. Ind. Eng. 2004, 55, 1011-1015. [CrossRef]

(C) 2018 by the authors. Licensee MDPI, Basel, Switzerland. This article is an open access article distributed under the terms and conditions of the Creative Commons Attribution (CC BY) license (http:// creativecommons.org/licenses/by/4.0/). 